\title{
Including unpublished surveys in reviews on Chagas disease in Mexico
}

\author{
Pierre Buekens $^{1 *} \mathbb{D}$, Jorge López-Cárdenas ${ }^{2}$, Eric Dumonteil ${ }^{1}$ and Nicolas Padilla-Raygoza ${ }^{3}$
}

\author{
* Correspondence: pbuekens@ \\ tulane.edu \\ ${ }^{1}$ School of Public Health and \\ Tropical Medicine, Tulane University, \\ 1440 Canal St., Suite 2001, New \\ Orleans, LA 70112, USA \\ Full list of author information is \\ available at the end of the article
}

\begin{abstract}
A consequence of the late awareness of Chagas disease in North America is that many early studies were never published in peer-reviewed journals and are not easily accessible for inclusion in systematic reviews. We reviewed data from the state of Guanajuato, Mexico, as an illustration. Three population-based surveys have been performed between 1991 and 2002 and were never fully published. Systematic reviews should recognize this publication bias.
\end{abstract}

Keywords: Chagas disease, Guanajuato, Mexico, Trypanosoma cruzi

\section{Background}

Chagas disease or American trypanosomiasis is a major cause of cardiac disease in the Americas [1]. Most of the efforts to control Chagas disease have been focused on South and Central America, while the awareness of Chagas disease is more recent in North America, including Mexico [2]. A recent systematic review of Mexican population-based data from 2006 to 2017 estimated the Trypanosoma cruzi national seroprevalence at 3.4\% [1]. Historically, Mexico has been divided into "endemic" and "non-endemic" areas for Chagas disease [3]. There is now a growing consensus that Chagas disease is a national problem in Mexico, regardless of the federal entity.

A consequence of the late awareness of Chagas disease in North America is that many early studies were never published in peer-reviewed journals and are not easily accessible for inclusion in systematic reviews. We will review data from the state of Guanajuato as an illustration. The state of Guanajuato is north of Mexico City and is one of the states sending more immigrants to the USA [4]. Detailed entomological studies have shown that the vector is present all over the state $[5,6]$. Three population-based surveys have been performed between 1991 and 2002 and were never fully published. A serological survey performed by Juárez Leyva in 1991 in San José de la Presa, Purísima del Rincón, Guanajuato, found a T. cruzi seroprevalence of $6.1 \%(n=228)$ [5, 7]. Another serological survey performed in Guanajuato in 1999-2000 in 60 communities found a seroprevalence of 2.6\% ( $n=1730$ ) [5]. A serological survey performed in Ciudad Manuel Doblado, Guanajuato, in 2002, found 2.0\% seroprevalence among 200 children and adolescents $<18$ years old [7].

(c) The Author(s). 2020 Open Access This article is licensed under a Creative Commons Attribution 4.0 International License, which permits use, sharing, adaptation, distribution and reproduction in any medium or format, as long as you give appropriate credit to the original author(s) and the source, provide a link to the Creative Commons licence, and indicate if changes were made. The images or other third party material in this article are included in the article's Creative Commons licence, unless indicated otherwise in a credit line to the material. If material is not included in the article's Creative Commons licence and your intended use is not permitted by statutory regulation or exceeds the permitted use, you will need to obtain permission directly from the copyright holder. To view a copy of this licence, visit http://creativecommons.org/licenses/by/4.0/. The Creative Commons Public Domain Dedication waiver (http://creativecommons.org/publicdomain/zero/1.0/) applies to the data made available in this article, unless otherwise stated in a credit line to the data. 
Studies performed more recently were published and showed seroprevalence of $0.8 \%$ in Celaya, Guanajuato, in 2006-2007 and of 3.8\% in León, Guanajuato, in 2014-2015 [8, 9]. The reported number of cases of Chagas disease from Guanajuato increased over time, suggesting a growing awareness of the disease [10].

\section{Conclusion}

Many studies on Chagas disease in Mexico were most likely not published in peerreviewed journals. Systematic reviews should recognize this publication bias and search for unpublished data as much as possible.

\section{Acknowledgements}

We thank Andrea Meyer for her help in editing the manuscript.

\section{Authors' contributions}

PB designed the concept of the study. All authors were involved in the literature review. All authors were involved in drafting the manuscript prior to submission. All authors read and approved the final manuscript.

\section{Funding}

Not applicable.

\section{Availability of data and materials}

Not applicable.

Ethics approval and consent to participate

Not applicable.

\section{Consent for publication}

Not applicable.

\section{Competing interests}

The authors declare that they have no competing interests.

\section{Author details}

${ }^{1}$ School of Public Health and Tropical Medicine, Tulane University, 1440 Canal St., Suite 2001, New Orleans, LA 70112, USA. ${ }^{2}$ Public Health State Laboratory of the State of Guanajuato, Leon, Guanajuato, Mexico. ${ }^{3}$ School of Medicine, University of Celaya, Celaya, Guanajuato, Mexico.

Received: 22 January 2020 Accepted: 3 November 2020

Published online: 11 November 2020

\section{References}

1. Arnal A, Waleckx E, Rico-Chávez O, Herrera C, Dumonteil E. Estimating the current burden of Chagas disease in Mexico: a systematic review and meta-analysis of epidemiological surveys from 2006 to 2017. Plos Negl Trop Dis. 2019;13(4):e0006859.

2. Buekens P, Almendares O, Carlier Y, Dumonteil E, Eberhard M, Gamboa-Leon R, et al. Mother-to-child transmission of Chagas' disease in North America: why don't we do more? Matern Child Health J. 2008;12(3):283-6.

3. Novelo-Garza BA, Benítez-Arvizu G, Peña-Benítez A, Galván-Cervantes J, Morales-Rojas A. Detection of Trypanosoma cruzi in blood donors. Rev Med Inst Mex Seguro Soc. 2010;48(2):139-44.

4. Yearbook of migration and remittances Mexico. Mexico City: CONAPO Consejo Nacional de Población; 2018.

5. López-Cárdenas J, Gonzalez Bravo FE, Salazar Schettino PM, Gallaga Solorzano JC, Ramírez Barba E, Martinez Mendez J, et al. Fine-scale predictions of distributions of Chagas disease vectors in the state of Guanajuato, Mexico. J Med Entomol. 2005;42(6):1068-81.

6. Salazar Schettino PM, Rosales Piña JS, Rojas Wastavino G, Cabrera Bravo M, Vences Blanco M, López CJ. Triatoma mexicana (Hemiptera: Reduviidae) in Guanajuato, Mexico: house infestation and seasonal variation. Mem Inst Oswaldo Cruz. 2007;102(7):803-7.

7. Peña-Archundia G. Estudio de la distribución espacial y parasitosis del vector de la enfermedad de Chagas y su seroprevalencia en menores de 18 años en el municipio de Manuel Doblado, estado de Guanajuato, del 2001 al 2003. León, Guanajuato: Universidad de Guanajuato; 2005.

8. Montes-Rincón LM, Galaviz-Silva L, González-Bravo FE, Molina-Garza ZJ. Trypanosoma cruzi seroprevalence in pregnant women and screening by PCR and microhaematocrit in newborns from Guanajuato, Mexico. Acta Trop. 2016;164:100-6.

9. Gamboa-León R, Gonzalez-Ramirez C, Padilla-Raygoza N, Sosa-Estani S, Caamal-Kantun A, Buekens P, et al. Do commercial serologic tests for Trypanosoma cruzi infection detect Mexican strains in women and newborns? J Parasitol. 2011;97(2):338-43.

10. Shelly EM, Acuna-Soto R, Ernst KC, Sterling CR, Brown HE. A critical assessment of officially reported Chagas disease surveillance data in Mexico. Public Health Rep. 2016;131(1):59-66.

\section{Publisher's Note}

